CZASOPISMO INŻYNIERII LĄDOWEJ, ŚRODOWISKA I ARCHITEKTURY JOURNAL OF CIVIL ENGINEERING, ENVIRONMENT AND ARCHITECTURE

JCEEA, t. XXXIV, z. 64 (3/I/17), lipiec-wrzesień 2017, s. 31-38, DOI: 10.7862/rb.2017.101

\author{
Halina GARBALIŃSKA ${ }^{1}$ \\ Jarosław STRZAŁKOWSKI ${ }^{2}$ \\ Agata STOLARSKA ${ }^{3}$
}

\title{
ANALIZA ROZKŁADU TEMPERATURY W ŚCIANIE ŻELBETOWEGO ZBIORNIKA, UWZGLĘDNIAJĄCA DWUWYMIAROWY PRZEPLYW CIEPŁA
}

\begin{abstract}
Artykuł prezentuje wybrane aspekty projektowania żelbetowych zbiorników na ciecze z uwagi na obciążenia termiczne, pojawiające się w trakcie ich eksploatacji. Obciążenia termiczne wynikają z występowania dużych różnic temperatur między cieczą wypełniającą zbiornik a jego otoczeniem. W szczególności problem ten ujawnia się $\mathrm{w}$ przypadku ścian zbiornika, wyniesionych ponad poziom terenu. Wartości obliczeniowych temperatur podane w normie EC1-1-5 ustalone zostały na ekstremalnie niskim poziomie dla warunków zimowych (w przeprowadzonych obliczeniach przyjmowano $-30^{\circ} \mathrm{C}$ ), natomiast dla okresu letniego na poziomie ekstremalnie wysokim (w obliczeniach przyjmowano $+38^{\circ} \mathrm{C}$ oraz $+56^{\circ} \mathrm{C}$, na ścianach zbiornika wyeksponowanych na działanie słońca). $\mathrm{W}$ obliczeniach zaprezentowanych $\mathrm{w}$ artykule poddano analizie 4 warianty rozwiązania ściany zewnętrznej zbiornika - bez izolacji termicznej oraz z ułożoną na zewnątrz izolacją ze styropianu o grubości 5,10 i $15 \mathrm{~cm}$. Obliczenia rozkładów temperatur w ścianie zbiornika wykonano przy użyciu oprogramowania CFD, używanego do symulacji stacjonarnych i niestacjonarnych procesów cieplnych. Porównanie danych otrzymanych z symulacji dwuwymiarowych z wynikami obliczeń zakładających jednowymiarowy przepływ ciepła, wskazuje na występowanie wyraźnie wyższych gradientów temperatur. Problem ten jest szczególnie istotny w ścianach z termoizolacją, gdzie różnice temperatury są nawet pięciokrotnie większe w rozpatrywanych przekrojach, niż w modelu jednowymiarowym. Przekłada się to w dalszej kolejności na naprężenia występujące w obrębie ściany zbiornika, a wywołane zmianami temperatury.
\end{abstract}

Słowa kluczowe: zbiornik na ciecze, ściana żelbetowa, obciążenia termiczne, naprężenia termiczne, oprogramowanie CFD

\footnotetext{
${ }^{1}$ Autor do korespondencji / corresponding author: Halina Garbalińska, Zachodniopomorski Uniwersytet Technologiczny w Szczecinie, Katedra Fizyki Budowli i Materiałów Budowlanych, al. Piastów 50, 70-311 Szczecin, tel. 9144942 91; Halina.Garbalinska@ zut.edu.pl

2 Jarosław Strzałkowski, Zachodniopomorski Uniwersytet Technologiczny w Szczecinie, Katedra Fizyki Budowli i Materiałów Budowlanych, al. Piastów 50, 70-311 Szczecin, tel. 9144943 41; jstrzalkowski@zut.edu.pl

${ }^{3}$ Agata Stolarska, Zachodniopomorski Uniwersytet Technologiczny w Szczecinie, Katedra Fizyki Budowli i Materiałów Budowlanych, al. Piastów 50, 70-311 Szczecin, tel. 9144943 41; siwinska@zut.edu.pl
} 


\section{Wprowadzenie}

Zbiorniki na ciecze znajdują szerokie zastosowanie w gospodarce, głównie w przemyśle spożywczym oraz chemicznym. Wykorzystywane są przy oczyszczaniu ścieków, służą do magazynowania wody pitnej, przemysłowej oraz przeznaczonej do celów przeciwpożarowych, jak również do przechowywania produktów naftowych, ale też występują przy innego rodzaju realizacjach np. jako baseny rekreacyjne lub sportowe.

W przypadku zbiorników na ciecze podstawową kwestią jest zapewnienie ich szczelności, co powoduje, że miarodajny w projektowaniu elementów składowych żelbetowego zbiornika nie jest stan graniczny nośności, ale stan graniczny użytkowalności - w zakresie zarysowania.

Głównym obciążeniem zbiornika otwartego jest ciśnienie cieczy wywierane na jego dno i ściany, a także przeciwnie skierowane do ciśnienia cieczy parcie gruntu, brane pod uwagę w przypadku zbiorników podziemnych i częściowo zagłębionych. Oczywiście w obliczeniach uwzględnia się także obciążenia stałe (ciężar własny przekrycia, ścian i dna, ciężar izolacji) oraz technologiczne, a także obciążenia środowiskowe, takie jak wiatr i śnieg (w przypadku zbiorników wyposażonych w przekrycie). Ponadto brane są pod uwagę obciążenia wyjątkowe, tj. obciążenia sejsmiczne, zewnętrzne wybuchy, uderzenia, pożary w strefach przyległych, eksplozje, czy przecieki.

Poza w/w obciążeniami elementy składowe zbiornika żelbetowego poddane są dodatkowym oddziaływaniom (m.in. termicznym), których pominięcie może prowadzić do niedoszacowania wartości sił wewnętrznych w projektowanych elementach, [2].

Oddziaływania termiczne szczególnie silnie ujawniają się przy dużej różnicy temperatur między cieczą wypełniającą zbiornik a jego otoczeniem. W literaturze [3] wyróżnia się dwa zasadnicze obciążenia termiczne, które spowodowane są różnicą $\Delta \mathrm{T}_{\mathrm{M}}$ między temperaturą wewnętrznej i zewnętrznej powierzchni ściany zbiornika oraz różnicą $\Delta \mathrm{T}$ między temperaturą początkową, a średnią temperaturą panującą wewnątrz ściany. Różnice temperatur należy wyznaczać na podstawie normy EC1-1-5 [5]. Opis i zastosowanie wzorów zalecanych w normatywach do oszacowania gradientu temperatur w obrębie ściany przykładowego zbiornika (patrz rys. 1.) przedstawiono w [1], zakładając zgodnie $\mathrm{z}$ zaleceniami jednowymiarowy przepływ ciepła w kierunku prostopadłym do ściany zbiornika.

W niniejszym artykule przeprowadzono w odniesieniu do tego samego zbiornika bardziej precyzyjne obliczenia symulacyjne, uwzględniające dwuwymiarowy przepływ ciepła. Ich wyniki wskazują na występowanie wyraźnie wyższych gradientów temperatur, skutkujących wyższymi wartościami naprężeń w stosunku do wyznaczonych na bazie modelu jednowymiarowego. 


\section{Przedmiot analiz}

Przeprowadzone analizy dotyczą zbiornika żelbetowego zlokalizowanego w Szczecinie. Jest to zbiornik oczyszczalni ścieków przy zakładzie produkcyjnym branży spożywczej. Ściana zbiornika ma założoną grubość $30 \mathrm{~cm}$ i przewidzianą izolację termiczną ze styropianu, wprowadzoną na głębokość $1,0 \mathrm{~m}$ poniżej poziomu gruntu. Płyta denna ma grubość $40 \mathrm{~cm}$. Średnica wewnętrzna zbiornika wynosi $30 \mathrm{~m}$. Rzut poziomy i przekrój poprzeczny zbiornika zobrazowano na rys. 1 . W zbiorniku znajdują się ścieki o dodatniej temperaturze, wynoszącej zimą $\mathrm{T}_{\text {in }}=10-15^{\circ} \mathrm{C}$, a latem $\mathrm{T}_{\text {in }}=17-25^{\circ} \mathrm{C}$.

W nawiązaniu do lokalizacji zbiornika, przyjęto parametry klimatu zewnętrznego na podstawie [5], a mianowicie zimą $-30^{\circ} \mathrm{C}$, latem $+38^{\circ} \mathrm{C}$. Przy uwzględ-
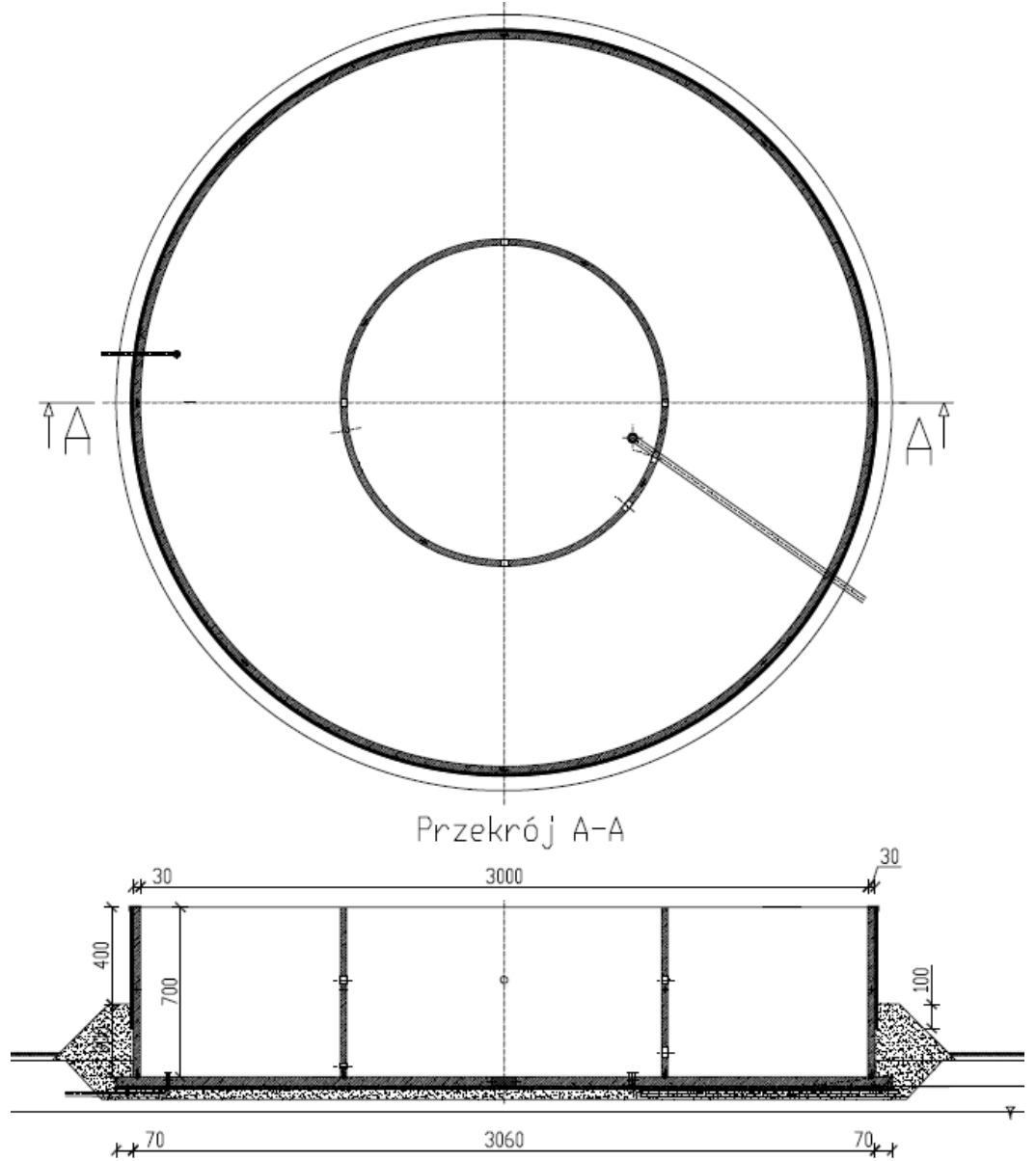

Rys. 1. Rzut poziomy i przekrój poprzeczny zbiornika ścieków [1]

Fig. 1. Layout and horizontal section of sewage tank [1] 
nieniu dodatkowego nagrzania przez promieniowanie słoneczne latem maksymalna temperatura zewnętrzna wynosi $+56^{\circ} \mathrm{C}$ (zwiększenie o $\left.+18^{\circ} \mathrm{C}\right)$, [5].

\section{Procedura badawcza i analiza wyników}

Obliczenia rozkładów temperatur w ścianie zbiornika wykonano przy użyciu oprogramowania CFD, służącego m.in. do symulacji stacjonarnych i niestacjonarnych procesów cieplnych. Wykonano trójwymiarowy model zbiornika, analizie poddając wycinek ściany o szerokości jednego metra. Testowano cztery przypadki:

- ściana bez izolacji,

- ściana z izolacją grubości $5 \mathrm{~cm}$,

- ściana z izolacją grubości $10 \mathrm{~cm}$,

- ściana z izolacją grubości $15 \mathrm{~cm}$.

Dodatkowo obliczenia wariantowano warunkami brzegowymi. W wariancie pierwszym przyjęto obliczeniową temperaturę powietrza zewnętrznego $\mathrm{T}_{\text {out }}=-30^{\circ} \mathrm{C}$, a temperaturę cieczy na najbardziej niekorzystnym poziomie, $\mathrm{tj} . \mathrm{T}_{\text {in }}=+15^{\circ} \mathrm{C}$. Na podstawie EC1-1-5 [5] przyjęto temperaturę $\mathrm{w}$ gruncie do głębokości jednego metra równą $-5^{\circ} \mathrm{C}$ oraz $-3^{\circ} \mathrm{C}$ poniżej. W wariancie drugim symulowano temperatury zbiornika $\mathrm{w}$ okresie letnim. Przyjęto temperaturę powietrza zewnętrznego $\mathrm{T}_{\text {out }}=+38^{\circ} \mathrm{C}$ i temperaturę cieczy $\mathrm{T}_{\text {in }}=+17^{\circ} \mathrm{C}$. Temperaturę gruntu dla okresu letniego, zgodnie z zaleceniami EC1-1-5 [5], do głębokości jednego metra przyjęto $+8^{\circ} \mathrm{C}$, a przy większej głębokości $+5^{\circ} \mathrm{C}$. $\mathrm{W}$ trzecim wariancie uwzględniono dodatkowo wpływ nagrzania ściany przez promieniowanie słoneczne, zwiększając temperaturę zewnętrzną do wartości $\mathrm{T}_{\mathrm{out}}=+56^{\circ} \mathrm{C}$.

We wszystkich przypadkach opór przejmowania ciepła od strony cieczy oraz przy gruncie założono jako równy $0,00\left(\mathrm{~m}^{2} \cdot \mathrm{K}\right) / \mathrm{W}$, [1]. Natomiast po stronie zewnętrznej założono wartość $0,04\left(\mathrm{~m}^{2} \cdot \mathrm{K}\right) / \mathrm{W},[6]$. Współczynnik przewodzenia ciepła $\mathrm{w}$ przypadku żelbetowej ściany zbiornika przyjęto $\lambda=2,30 \mathrm{~W} /(\mathrm{m} \cdot \mathrm{K})$ oraz $\mathrm{w}$ przypadku izolacji termicznej $\lambda=0,04 \mathrm{~W} /(\mathrm{m} \cdot \mathrm{K})$ [7].

Wynikiem symulacji było wyznaczenie rozkładów temperatury (rys. 2-4) w ścianie zbiornika w poszczególnych przypadkach rozwiązania izolacji i różnych wariantach założonej temperatury wewnątrz i na zewnątrz. Różnice między temperaturą na wewnętrznej powierzchni zbiornika, a temperaturą na zewnętrznej jego powierzchni na trzech charakterystycznych poziomach ściany zbiornika zestawiono $\mathrm{w}$ tabeli 1 . Na rysunku 2. przedstawiono rozkład temperatury $\mathrm{w}$ ścianie zbiornika w warunkach zimowych, a na rys. 3-4 w warunkach letnich.

Zilustrowane na rysunku 2. rozkłady temperatur dotyczą najbardziej niekorzystnych warunków panujących zimą, gdy temperatura ścieków wynosi $+15^{\circ} \mathrm{C}$, a temperatura zewnętrzna $-30^{\circ} \mathrm{C}$. Z kolei zestawione na rysunkach 3-4 rozkłady temperatur dotyczą najbardziej niekorzystnych warunków w sezonie letnim, przy temperaturze ścieków przyjętych na poziomie $+17^{\circ} \mathrm{C}$ oraz wariantowo 
przyjętej temperaturze zewnętrznej: $+38^{\circ} \mathrm{C}$ (powierzchnia nienasłoneczniona) oraz $+56^{\circ} \mathrm{C}$ (jasna powierzchnia zbiornika wyeksponowana na działanie promieni słonecznych).

Tabela 1. Zestawienie danych dla trzech rozpatrywanych wariantów

Table 1. Data summary for the three examined variants

\begin{tabular}{|c|c|c|c|c|c|c|}
\hline Wariant & $\begin{array}{l}\mathbf{T}_{\text {out }} \\
{\left[{ }^{\circ} \mathbf{C}\right]}\end{array}$ & $\begin{array}{c}\mathbf{T}_{\text {in }} \\
{\left[{ }^{\circ} \mathbf{C}\right]}\end{array}$ & $\begin{array}{c}\text { Izolacja } \\
\text { [cm] }\end{array}$ & $\begin{array}{c}\Delta \mathrm{T}_{\mathrm{M}} \text { na } \\
\text { wysokości } \\
\text { lustra cieczy }\end{array}$ & $\begin{array}{c}\Delta \mathrm{T}_{\mathrm{M}} \text { na } \\
\text { wysokości } \\
\text { poziomu } \\
\text { terenu }\end{array}$ & $\begin{array}{c}\Delta T_{M} \text { na } \\
\text { poziomie dol- } \\
\text { nej krawędzi } \\
\text { izolacji }\end{array}$ \\
\hline \multirow{4}{*}{ I } & \multirow{4}{*}{-30} & \multirow{4}{*}{+15} & 0 & 37,94 & 19,94 & 18,71 \\
\hline & & & 5 & 19,24 & 2,88 & 18,76 \\
\hline & & & 10 & 18,02 & 1,58 & 18,75 \\
\hline & & & 15 & 17,58 & 1,10 & 18,78 \\
\hline \multirow{4}{*}{ II } & \multirow{4}{*}{+38} & \multirow{4}{*}{+17} & 0 & 17,70 & 8,81 & 10,09 \\
\hline & & & 5 & 8,97 & 0,31 & 9,95 \\
\hline & & & 10 & 8,41 & 0,18 & 9,95 \\
\hline & & & 15 & 8,20 & 0,12 & 9,92 \\
\hline \multirow{4}{*}{ III } & \multirow{4}{*}{+56} & \multirow{4}{*}{+17} & 0 & 32,88 & 8,74 & 10,09 \\
\hline & & & 5 & 16,67 & 1,02 & 9,95 \\
\hline & & & 10 & 15,61 & 0,57 & 9,95 \\
\hline & & & 15 & 15,23 & 0,39 & 9,92 \\
\hline
\end{tabular}

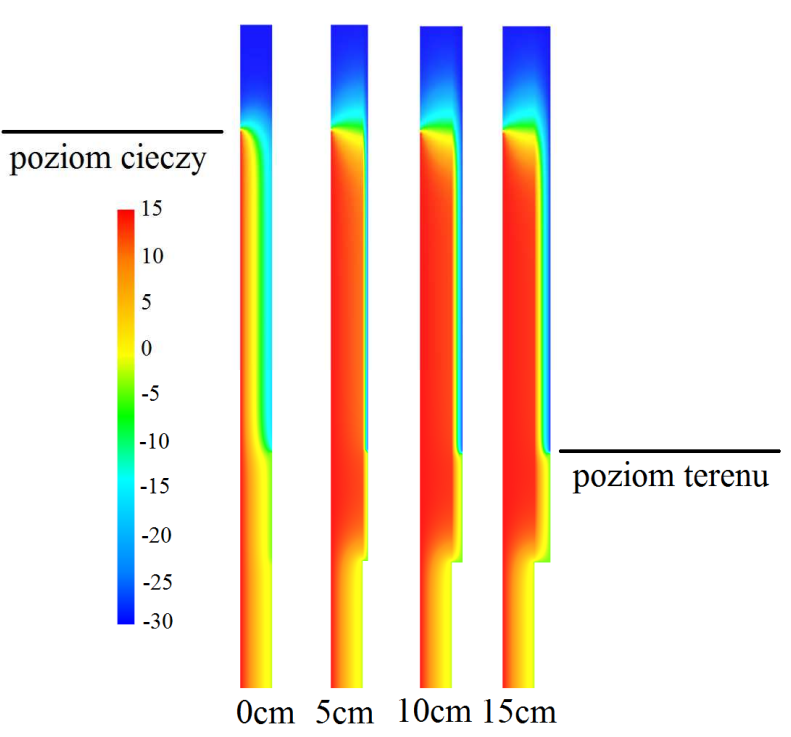

Rys. 2. Rozkład temperatury w ścianie zbiornika przy $\mathrm{T}_{\text {in }}=+15^{\circ} \mathrm{C}$ i $\mathrm{T}_{\text {out }}=-30^{\circ} \mathrm{C}$

Fig. 2. Temperature distribution in tank wall at $\mathrm{T}_{\text {in }}=+15^{\circ} \mathrm{C}$ and $\mathrm{T}_{\text {out }}=-30^{\circ} \mathrm{C}$ 


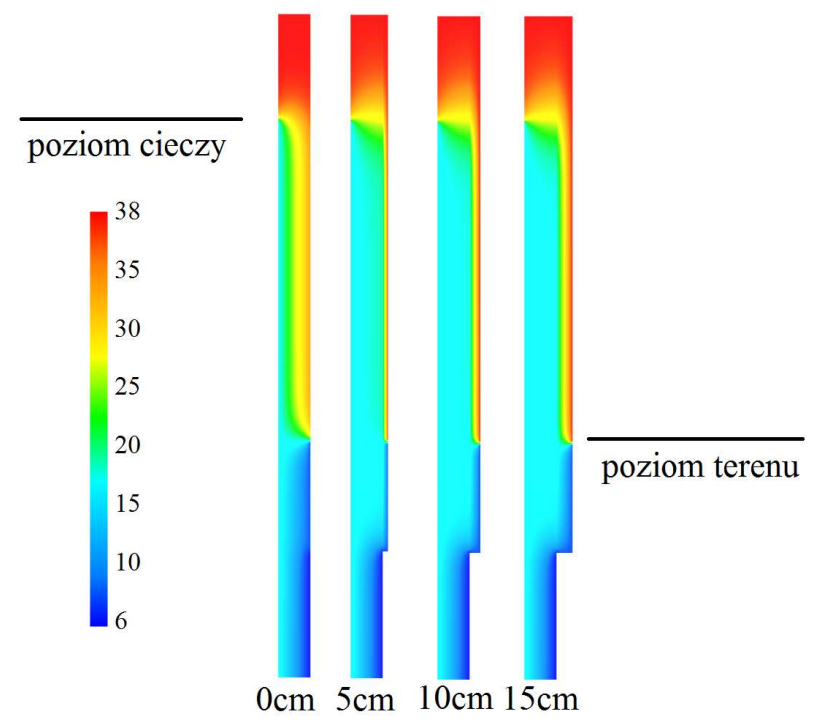

Rys. 3. Rozkład temperatury w ścianie zbiornika przy $\mathrm{T}_{\text {in }}=+17^{\circ} \mathrm{C}$ i $\mathrm{T}_{\text {out }}=+38^{\circ} \mathrm{C}$

Fig. 3. Temperature distribution in tank wall at $\mathrm{T}_{\text {in }}=+17^{\circ} \mathrm{C}$ and $\mathrm{T}_{\text {out }}=+38^{\circ} \mathrm{C}$

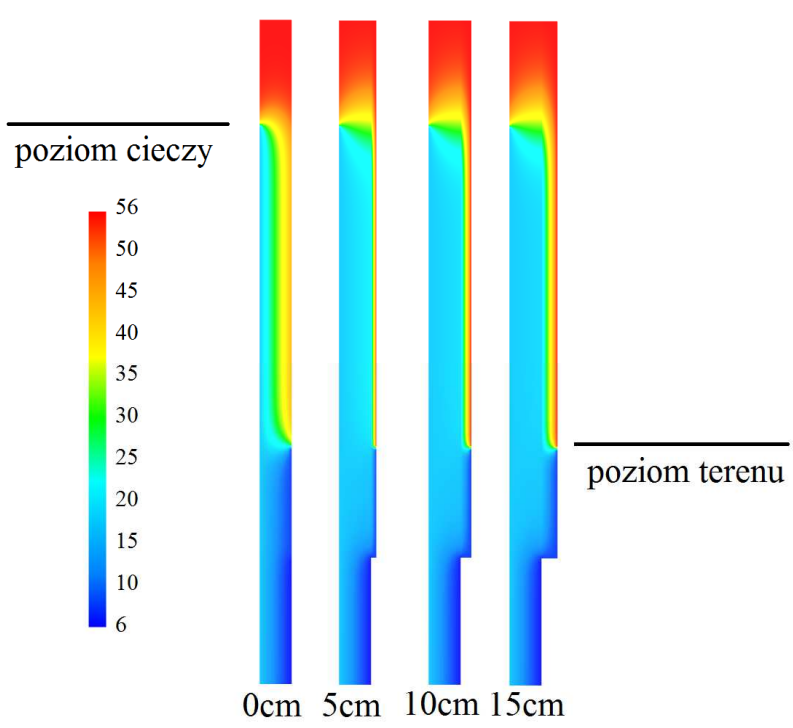

Rys. 4. Rozkład temperatury w ścianie zbiornika przy $\mathrm{T}_{\text {in }}=+17^{\circ} \mathrm{C}$ i $\mathrm{T}_{\text {out }}=+56^{\circ} \mathrm{C}$

Fig. 4. Temperature distribution in tank wall at $\mathrm{T}_{\text {in }}=+17^{\circ} \mathrm{C}$ and $\mathrm{T}_{\text {out }}=+56^{\circ} \mathrm{C}$ 


\section{Podsumowanie}

W każdym rozpatrywanym wariancie warunków termicznych (I, II, III) występujących po obydwu stronach zbiornika, największe różnice temperatur występują przy analizie modelu bez termoizolacji (por. tab. 1.). Sięgają one $38^{\circ} \mathrm{C}$ na wysokości lustra cieczy.

Natomiast w przypadkach z zastosowaną termoizolacją różnice temperatury są niewielkie, ale wyłącznie na odcinku, w którym występuje jednokierunkowy przepływ ciepła, co ma miejsce w strefie lokującej się między poziomem lustra cieczy, a poziomem gruntu.

Stosunkowo duże gradienty $\Delta \mathrm{T}_{\mathrm{M}}$, sięgające nawet 19 stopni, występują w ścianach z izolacją na wysokości lustra cieczy. W tej strefie mamy do czynienia z dwukierunkowym przepływem ciepła, co ujawnia się jako wyraźne zakrzywienie izoterm widoczne na rysunkach 2-4.

Podobnie w miejscu zakończenia izolacji cieplnej w gruncie gradient $\Delta \mathrm{T}_{\mathrm{M}}$ osiąga wartości bliskie 19 stopni w okresie zimowym i około 10 stopni w okresie letnim. W tej strefie przegrody również występują wyraźne zaburzenia jednokierunkowego przepływu ciepła.

Na poziomie terenu duży wpływ na uzyskiwane wyniki ma założona temperatura w gruncie, przyjęta zgodnie z zaleceniami [5]. Jej wpływ jest szczególnie widoczny przy rozpatrywaniu przypadków bez izolacji termicznej, gdzie $\Delta \mathrm{T}_{\mathrm{M}} \mathrm{W}$ okresie zimowym wynosi prawie 20 stopni. W sezonie letnim wielkość $\Delta \mathrm{T}_{\mathrm{M}}$ jest mniejsza i nie przekracza 9 stopni. Zastosowanie izolacji skutkuje znacznym obniżeniem gradientów temperatury na tym poziomie.

Zilustrowane graficznie wyniki (rys. 2-4) uwidaczniają zróżnicowane efekty termiczne wariantowego rozwiązania izolacji. Wyraźnie widać wpływ zastosowanej termoizolacji na różny rozkład izoterm w poszczególnych przypadkach.

Porównując otrzymane dane z symulacji dwuwymiarowych z wynikami obliczeń zakładających jednowymiarowy przepływ ciepła [1], zauważono wyraźnie bardziej niekorzystne gradienty, których model jednowymiarowy nie wykazuje. Problem ten jest szczególnie istotny w ścianach z termoizolacją, gdzie różnice temperatury są nawet pięciokrotnie większe w rozpatrywanych płaszczyznach niż w modelu jednowymiarowym. Przekłada się do w dalszej kolejności na wyższe wartości naprężeń, związanych $\mathrm{z}$ oddziaływaniem temperatury na ścianę zbiornika.

W planach autorów jest kontynuowanie analiz, w kierunku dalszego urealnienia opisu rozpatrywanych zjawisk termicznych. W pierwszej kolejności przewiduje się przeprowadzenie symulacji porównawczych odnoszących się do stref zbiornika zagłębionych w gruncie. Podawane w EC1-1-5 [5] wartości temperatur do głębokości $1 \mathrm{~m}$ i poniżej (np. zimą: $-5^{\circ} \mathrm{C}$ i $-3^{\circ} \mathrm{C}$ ) odbiegają istotnie od faktycznych rozkładów temperatury na głębokości gruntu (por. np. [1, 4, 7]) i skutkują niepotrzebnym przeszacowaniem gradientów temperatury wyznaczanych w odniesieniu do tej strefy. 


\section{Literatura}

[1] Garbalińska H., Stolarska A., Strzałkowski J., Figiel E.: Wyznaczanie rozkładu temperatur w ścianie żelbetowego zbiornika na ciecze, XVI Polska Konferencja NaukowoTechniczna „Fizyka Budowli w Teorii i Praktyce”, Łódź-Słok 20-22 czerwca 2017.

[2] Halicka A.: Specyfika projektowania zbiorników na ciecze, Inżynier budownictwa, 2014, nr 12, s. 82-88.

[3] Halicka A., Franczak D.: Projektowanie zbiorników żelbetowych, Zbiorniki na ciecze, Tom 2, Wydawnictwo Naukowe PWN, Warszawa 2013.

[4] Kostka M., Szulgowska-Zgrzywa M.: Obliczenia energetyczne gruntowych rurowych wymienników ciepła, Rynek Instalacyjny, czerwiec 2015, s. 64-68.

[5] PN-EN 1991-1-5 Eurokod 1. Oddziaływania na konstrukcje. Część 1-5. Oddziaływania ogólne. Oddziaływania termiczne.

[6] PN-EN ISO 6946:2008 Komponenty budowlane i elementy budynku. Opór cieplny i współczynnik przenikania ciepła. Metoda obliczania.

[7] Tarnawski P.: Analiza CFD wydajności rurowego gruntowego wymiennika ciepła, Rynek Instalacyjny, czerwiec 2015, s. 70-72.

\section{ANALYSIS OF TEMPERATURE DISTRIBUTION IN THE REINFORCED CONCRETE WALL OF TANK, CONSIDERING TWO-DIMENSIONAL HEAT FLOW}

\section{S u m m a r y}

The article presents the selected aspects of designing reinforced concrete tanks for liquids considering the high thermal loads occurring during tanks' exploitation. Thermal loads often are a consequence of occurrence of high differences in temperature between the liquid, which fills the tank, and the tank's surroundings. This problem is strongly visible in case of the tank's walls erected high above ground level. The calculation values of temperatures presented by EC1-1-5 norm have been established on extremely low levels of winter conditions (during the calculations, the assumed temperature was $-30^{\circ} \mathrm{C}$ ), and extremely high levels of summer conditions (during the calculations, the assumed temperature was $+38^{\circ} \mathrm{C}$ and $+56{ }^{\circ} \mathrm{C}$ on the tank's walls exposed to sunlight). The calculations presented in the article included 4 variants of solutions for the tank's external walls - devoid of thermal isolation and with isolation of 5, 10 and $15 \mathrm{~cm}$ thick polystyrene layers laid out externally. Calculations of temperature distribution in the tank wall were made with application of CFD software which is used to simulate stationary and non-stationary heat processes. The comparison of data obtained from the two-dimensional simulation with results assuming one-dimensional heat flow indicates the appearance of clearly higher temperature gradients. The problem is particularly important in walls with thermal insulation, where temperature differences are even five times higher in the section in question than in the one-dimensional model. It further results in stresses appearing within the tank walls, which are caused by temperature changes.

Keywords: liquids tank, reinforced concrete wall, thermal loads, thermal stresses, CFD software

Przestano do redakcji: $20.06 .2017 \mathrm{r}$.

Przyjęto do druku: 01.09.2017 r. 